Meta

Journal des traducteurs

Translators' Journal

\title{
Translation Research in the Framework of the Tel Aviv School of Poetics and Semiotics
}

\section{Rachel Weissbrod}

Volume 43, numéro 1, mars 1998

La traduction et l'interprétation en Israël

Translation and Interpreting in Israel

URI : https://id.erudit.org/iderudit/004592ar

DOI : https://doi.org/10.7202/004592ar

Aller au sommaire du numéro

Éditeur(s)

Les Presses de l'Université de Montréal

ISSN

0026-0452 (imprimé)

1492-1421 (numérique)

Découvrir la revue

Citer cet article

Weissbrod, R. (1998). Translation Research in the Framework of the Tel Aviv School of Poetics and Semiotics. Meta, 43(1), 35-45.

https://doi.org/10.7202/004592ar
Résumé de l'article

Israël a apporté une contribution importante à la traductologie. Depuis la fin des années 1960, cette contribution est largement identifiée à l'École de poétique et de sémiotique de l'Université de Tel-Aviv, dite École de Tel-Aviv. Cet article se propose de présenter les idées fondamentales de l'École de Tel-Aviv et de retracer leur développement. Il passe en revue les réalisations dans les diverses disciplines traductologiques : théorie, recherche descriptive et sciences appliquées. Il examine leur influence sur la recherche actuelle en traductologie. Abordant quelques échecs qui, aux yeux de l'auteur, sont susceptibles d'entraver le développement de l'école, l'article indique les directions à venir en matière de recherche et les défis que l'école doit encore relever. 


\title{
TRANSLATION RESEARCH IN THE FRAMEWORK OF THE TEL AVIV SCHOOL OF POETICS AND SEMIOTICS*
}

\author{
RACHEL WEISSBROD \\ The Hebrew University of Jerusalem and Beyt Berl College, Israel
}

Résumé

Israël a apporté une contribution importante à la traductologie. Depuis la fin des années 1960, cette contribution est largement identifiée à l'École de poétique et de sémiotique de l'Université de Tel-Aviv, dite École de Tel-Aviv. Cet article se propose de présenter les idées fondamentales de l'École de Tel-Aviv et de retracer leur développement. Il passe en revue les réalisations dans les diverses disciplines traductologiques : théorie, recherche descriptive et sciences appliquées. Il examine leur influence sur la recherche actuelle en traductologie. Abordant quelques échecs qui, aux yeux de l'auteur, sont susceptibles d'entraver le développement de l'école, l'article indique les directions à venir en matière de recherche et les défis que l'école doit encore relever.

\begin{abstract}
Israel has made an important contribution to translation studies. Since the late 1960s, its contribution in this field is mainly identified with the Tel Aviv school of poetics and semiotics. This paper sets out to introduce the basic ideas of the Tel Aviv school and show how they developed. It surveys the school's achievements in the various branches of translation studies - theory, descriptive research and the applied branches, and examines its impact on translation research in the world. Taking into account some shortcomings which in the author's view might interfere with the school's development, the paper points out the school's future directions of research and the challenges still to be met.
\end{abstract}

\section{HISTORICAL BACKGROUND}

Israel has made an important contribution to translation studies. Since the late 1960s, its contribution in this field is mainly identified with the Tel Aviv school of poetics and semiotics. The research group and approach thus titled emerged in the Department of Poetics and Comparative Literature at Tel Aviv University, and for a long time was largely identified with it. ${ }^{1}$ The founders of the department are Benjamin Hrushovski (later Harshav) - poet, literary researcher and semiotician, now at Yale University - and several of his students and colleagues. In 1966, they left the Hebrew University in Jerusalem in order to establish a new literature department, based on a new conception, at Tel Aviv University, which had been founded in the previous decade. Their objective was to deal neither with one specific national literature nor with comparative literature, but rather with poetics - the study of literature as literature. ${ }^{2}$ Their main goal was the development of a theory of literature. Descriptive research was to be conducted in the framework of a set of theoretical assumptions and was not to be confined a priori to any specific object. ${ }^{3}$ This approach, which guided the founders of the department, also found expression in its institute of research, the Porter Institute for Poetics and Semiotics, founded in 1975, and in its periodicals, Ha-Sifrut (Literature), which appeared in Hebrew in 1968-1986, PTL (Poetics 
and Theory of Literature), which appeared in English in 1976-1978, and its successor, Poetics Today, which has been appearing since 1979.

The general approach of Hrushovski and his followers, and the theories which they have developed in its framework, were largely influenced by research conducted in Eastern Europe. They relied to a great extent on the Russian formalists of the 1920s - Viktor Shklovskij, Jurij Tynjanov, Boris Ejxenbaum, Roman Jakobson and others, and their successors in the following decade, mainly the structuralists of Prague, including Jan Mukařovský and Peter Bogatyrëv. ${ }^{4}$ However, from the start, some members of the department were more interested in Anglo-American literary criticism. With the growing Westernization of Israeli culture, the emphasis of research among the faculty of the department shifted to Western theories: at first, theories of text structure, and later, post-modernist theories, theories of intertextuality and more.

The following discussion will focus on the work of a group which currently operates under the name "culture research group" and is no longer part of the department. The study of translation, in the broader context of the study of literature and semiotics of the culture, which is identified with the Tel Aviv school, is principally the achievement of the members of this group, mainly Itamar Even-Zohar and Gideon Toury. The latter is at present head of the culture research group.

\section{BASIC IDEAS}

\subsection{Polysystem Theory}

On the basis of formalism and structuralism, two directions of research began to develop in the earliest days of the department, merging during the 1970s: the study of literature in terms of a system, and the study of translation. The main impetus for the study of literature as a system was provided by Even-Zohar (representative works: 1971, 1978, 1990). Based on formalism, he assumed that literature, like other cultural activities, is to be seen as a system - a network of relations among phenomena, both concrete (texts, authors, publishers) and abstract (status within the system, methods of advertising and marketing, textual models). Following the formalists, he assumed that the system was an open and dynamic entity, into and out of which phenomena passed and flowed. This latter assumption was a drastic departure from the perception of the Geneva school, Ferdinand de Saussure and his followers, who by the end of the 19th century and the beginning of the 20th had used the concept of a system in the realm of language, but saw it as a static entity, closed within determined boundaries (Saussure 1983 [1916]).

Even-Zohar both accepted and continued to develop the concept of literature as a system. First he suggested viewing literature as a polysystem, a system of systems, which can be described by a series of oppositions: between the center (which dictates norms and models to the entire polysystem) and the periphery, between the canonized system (which usually occupies the center of the polysystem) and the non-canonized, between the systems of adult and children's literature, between translated and non-translated literature. Even-Zohar claimed that there was no point in researching each of these systems as if it operated in a vacuum; rather, one had to consider that its structure was the consequence of its relationship with other systems in this and other polysystems.

\subsection{Polysystem Theory and a Target-Oriented Approach to Translation}

Central assumptions of polysystem theory as formulated by Even-Zohar led him and his followers to take particular interest in translation. These assumptions were: 
Literature develops while in contact with other literatures. This contact may be expressed in the "translation" of models (as follows) as well as through the translation of concrete texts.

Translated literature is a part of the literary polysystem. It may be positioned at the center of the polysystem, in its periphery, or in any one of its systems, and can even be distributed among several systems. It may be a bastion of conservatism or a channel for innovation, and often the history of the polysystem cannot be understood without relating to it.

Following these assumptions, the foundations were laid for a theory of translation whose uniqueness with regard to other paradigms was its target-orientedness. It focused on the translated texts themselves, their position and role within the target culture, and their relations with original texts of that culture. ${ }^{5}$ According to this approach, "real" translations were not the only issues relevant to research in the field of translation, but also pseudo-translations - original texts of a given culture which were disguised as translations. Such a disguise was often used to introduce new models into a conservative literary polysystem, which did not tolerate innovations unless they were perceived as a foreign import (see Yahalom 1980 and 1981; pseudo-translations and their significance in translation studies are discussed in Toury $1995: 40-52$ ).

\subsection{Translation Norms and Repertoire}

Norms were a central concept in the study of translation by the Tel Aviv school. The concept of norms was introduced to semiotics, linguistics and literary studies by researchers such as Mukařovský (1970), Hrushovski (1971) and Coseriu (1988). As far as is known, this concept was first used in translation studies by Jiř́ Levý, a follower of the Prague structuralists (Levý 1963; German version 1969). It reappeared in the doctoral dissertation of Itamar Even-Zohar (1971) and in later works of his (particularly 1978), and received momentum in the works of Gideon Toury $(1977,1980,1995)$.

The norms are "do's and dont's", not necessarily formulated, which apply to various areas of behavior in society. They are social in nature and in that they differ from both personal factors which affect the behavior of people in society and universal behavior patterns.

Norms also apply to "translational behavior." Moreover, they have a central role in determining this behavior. In the stages prior to the act of translating itself, they dictate the selection of texts to be translated, determining what source languages and models should be preferred by a given target literature. They may encourage or delegitimize the production of mediated ("second hand") translations and pseudo-translations. Norms also play a central role in dictating the mode of translation (e.g., what linguistic variant to choose) and consequently they determine the relations between source and target text. Toury (1995 : 241-258) suggests that translators get to know the translation norms and learn to obey them in the process of their work in a socio-cultural context and with feedback from publishers, critics and readers. However, these norms are often internalized and adherence to them comes from the force of inner faith.

Norms, more than any other factor, determine the position of translations on an imaginary axis between two extreme possibilities - adequacy and acceptability. According to Even-Zohar and Toury, adequacy means a functional equivalence between source and target text. Such an equivalence is achieved by reconstructing the original functions of the elements comprising the source text. When translated literature occupies a central position in the literary polysystem and functions as a vehicle for introducing innovations into that polysystem, one may expect the norms to encourage translators to strive for such an equivalence (Even-Zohar 1990 : 45-51). However, it is doubtful whether total functional equivalence can be achieved. Even when desired, the differences between 
source and target language usually necessitate deviations from the source text. Moreover, it is assumed that the tendency for non-obligatory shifts from the source, which cannot be attributed to the different structures of source and target languages, is a universal of translation.

The tendency to make such non-obligatory shifts grows when the norms of translation demand acceptability — adjusting the translated text to the system receiving it. This usually happens when translated literature occupies a peripheral position in the polysystem and consequently is not "allowed" to function as a channel for innovation.

It is assumed that in any system, the production of texts is governed by a repertoire of textual elements together with their rules of combination (Even-Zohar 1990 : 17-19). A group of elements which is organized according to those rules is a model, which is an abstract formula for the creation of texts. A source text may be based on an existing model in the repertoire of the source system, or it may use elements in a unique manner, not according to their habitual combinations. In any case, the stronger the demand for acceptability, the greater the chance that the translated text will be adjusted to a model which already exists in the repertoire of the target system and is familiar to both the translator and target audience.

\subsection{Focusing on Real-World Phenomena}

The concepts and distinctions described above combine to form a theory of translation, whose main justification is in that it does not force itself on reality. In other paradigms, attempts to define translation according to criteria fixed a priory led to a rupture between research and reality (for the debate with some of them see Toury $1980: 35-50$, 63-70). Many, and sometimes most, of the texts regarded as translations in a given culture could not be considered as translations according to these definitions. Logically, these texts should have been excluded from translation research or at most treated as variations, adaptations, etc. In fact, the researchers often contradicted themselves by treating as translations texts which did not conform to their own definitions.

The concepts and distinctions developed by the Tel Aviv school - obligatory as opposed to non-obligatory shifts, norms of translation, acceptability and adequacy, adjustment to familiar models from the "home repertoire" — have made real-world phenomena the proper object for research. The assumption underlying them is that translation is conceived differently in different cultures and in different periods. Thus it is not impossible that what is considered a "good translation" under certain circumstances would not be considered good, or even a translation at all, under other circumstances, in a different culture or at a different time.

\section{THE SCHOOL'S DESCRIPTIVE RESEARCH}

A theory which regards translation as a culture-bound phenomenon calls for descriptive research. The need for such research, both for the sake of itself and for testing the theory, is the rationale for Toury's new book, ${ }^{6}$ published in 1995. Descriptive research on a variety of subjects was indeed conducted by Even-Zohar and Toury, as well as by their disciples. To mention just a few works: Even-Zohar (1990) analyzed the Russification of Hebrew culture. In this process, which lasted until the 1950s, translations played an important role. The norms of literary translation from German and English, which were marginal, while translations from Russian occupied the center of translated literature in Hebrew, were studied by Toury $(1977,1980$ : 122-139). Ben-Shahar (1983, 1992) focused on the language of dialogue as a specific translation problem, and analyzed its normdependent treatment in translations of prose fiction and theater scripts from English and 
French into Hebrew. Shavit (1986) and Ben-Ari (1992) examined the manipulations performed in adapting English and German texts to Hebrew children's literature. AmitKochavi and Kayyal are writing doctoral dissertations on subjects of utmost importance to Israeli culture: translations from Arabic to Hebrew and vice versa (see also Amit-Kochavi 1993). My own work (Weissbrod 1991) examines the relations between canonized and non-canonized literary translations from English into Hebrew. These and other works do not only shed light on the history of translation, mainly into Hebrew, but they also put to the test the theory itself, in whose framework they have been conducted, and add new aspects to it. For instance, Ben-Ari's work (1988) on literary translation from German into a variety of languages - English, French and Italian - testifies to the recurrence of some translation norms in various cultures, and raises the question - to be further examined whether they are universals of translation.

\section{APPLICATION OF THE RESEARCH ACHIEVEMENTS IN TRANSLATION AND CRITICISM}

The theoretical concepts and distinctions developed by the Tel Aviv school have been of use in applied areas as well. They have proven useful in the criticism of translation. For instance, on the basis of research of the elevated style used in literary translation into Hebrew, Toury (1974) argued in favor of spoken Hebrew as a legitimate language for translation.

The research achievements have also been utilized in the training of translators, particularly the training given in workshops at Tel Aviv University. In these workshops, students have been made conscious of the various factors which affect translating. They have become familiar with contemporary norms, to be either obeyed or rejected (usually at a price).

The school's presence has also been felt in the practical world. Over the years, many of its members have done translations for various publishing houses. One of them, "Hakibbutz Hameuchad", hosts the "Siman Kri'a" series, which was founded by Menakhem Perry, himself one of the "founding fathers" of the Tel Aviv school. In the 1970s and after, "Siman Kri'a" represented new directions in literary translation, influenced by the school's ideas. It played a role in placing Anglo-American literature at the center of translated literature in Hebrew, and in freeing literary translation from the elevated language favored by former generations.

\section{THE RELATIONS BETWEEN THEORY, DESCRIPTIVE RESEARCH AND THE APPLIED BRANCHES}

As shown, the activity of the school has encompassed all branches of the discipline of translation studies - theoretical, descriptive and applied, and has allowed for interactive links among them. The theory has guided descriptive research, which in turn has contributed to the correction and improvement of the theory, and the applied branches have been nourished by the other two. Yet, the researchers of the school attributed considerable importance to a clear distinction between the various branches of translation studies. Without this distinction there is room for common errors, first and foremost for presenting personal or norm-governed preferences as objective generalizations about the reality in question. The distinction between "pure" research, both theoretical and descriptive, and the applied branches, lay at the foundation of the Tel Aviv School's literary studies. But in applying this distinction specifically to the field of translation, the school's researchers also responded to the call of James S. Holmes of the University of Amsterdam. Holmes, one of the leading figures in modern translation research, claimed that the lack of a clear 
distinction between the branches of translation studies, as accepted in older and better-formulated disciplines such as linguistics, was one of the main obstacles to the development of research in this area (Holmes 1988; first in 1972).

\section{FUTURE DIRECTIONS}

After twenty five years of research activity, much is still to be done. Descriptive research has by no means exhausted even literary translation into Hebrew, a relatively small field. Theoretical research, too, has new goals. A methodology is being developed to explore such subjects as the process of translation and how it explains the existence of universal "laws" of translation (Toury 1995). The possibility of applying the theory to additional phenomena is being explored. The study of translation as described here originally focused mainly on translated literature. Today, attempts are being made to examine the validity of the proposed assumptions beyond the boundaries of literature, in other kinds of translation. In teaching, attempts are being made to broaden the concept of the non-obligatory shift, to include not only changes which are the consequence of language structure, but also those which result from the character of the medium and the mode of translation. Thus broadened, the concept will permit a distinction between obligatory and non-obligatory shifts in research concerning sub-titles and dubbing in films and television series, and will help to identify the norms operating in them as well. Furthermore, preliminary research is under way (Shlesinger 1989a and 1989b) regarding the applicability of the concept of norms to simultaneous translation, where there is no control of the product such as by critical articles, as there is in literary translation.

\section{TRANSLATION AND TRANSFER}

A particularly challenging field which has developed in the framework of polysystem theory, and which includes many possibilities for the future, is the attempt to address translation as one phenomenon in a broader context of interrelated phenomena, and to study the relations among these phenomena.

Since the inception of polysystem theory there has been a tendency to address translation as part of a series of phenomena, which Even-Zohar (1990: 73-78) proposed calling transfer. After Jakobson (1971), this included not only interlingual translation (as translation is usually understood), but also intralingual (the transformation of texts within the same language) and inter-semiotic (translation from medium to medium). Even-Zohar added to these the phenomenon of the "translation" of models for producing texts. In all these cases a text or model is transferred from one system to another - within the same culture or from culture to culture. On this basis, polysystem theory and the theory of translation developed in that framework were applied to studies of various types of transfer. Shavit (1986) explored the modification of texts from adult literature to children's literature. My dissertation (1989) deals with the adaptation of world classics to the Hebrew non-canonized literary system. Gertz (1993) examined the adaptation of literary works to the cinema (see also Weissbrod, forthcoming). The transfer of models was analyzed by Yahalom (1980 and 1981) in studies on connections between English and French literature in the 18th century. Sheffy (1985) studied the penetration of models of Western rock into Israeli songwriting. Benhabib (1985) examined the penetration of models of the American press into the Israeli one. Drory (1988) analyzed the connections between Hebrew and Arabic poetry in the 10th century. Many more subjects await exploration, which would possibly remain completely unnoticed unless researchers are inspired by polysystem theory. 


\section{THE SCHOOL'S IMPACT}

The above discussion summarizes the research achievements of the school as manifested in M.A. and doctoral dissertations, articles and books - mainly in Hebrew and English. It has also pointed at some of the school's future directions. However, in the academic world, the success of any approach is measured by its impact. One must therefore ask to what extent the school has succeeded in imparting its perceptions and concepts in the field of translation, in Israel and abroad. In Israel, the students of Even-Zohar and Toury at Tel Aviv University have found their place in other academic institutions - The Hebrew University, Bar Ilan University, The Open University, Beit Berl College, Oranim College and more, and they continue to apply the school's concepts in teaching and research. Abroad, the school's influence has been felt since the 1970s, particularly following the conference "Literature and Translation" in Leuven, 1976. The school has made its mark at several translation study centers, particularly in Belgium and the Netherlands, in the work of José Lambert, André Lefevere, Raymond van den Broeck, Theo Hermans, Dirk Delabastita, Lieven D'Hulst, Clem Robyns and others. The influence of researchers who base their work on polysystem theory is prominent in CETRA (previously CERA), the annual summer seminar at Leuven, which has in recent years attracted students of research from all over the world. New directions emerging in research in Israel, such as the attempt to apply polysystem theory to the study of the relationship between literature and film, have been taken up in research conducted in those centers as well (e.g. Cattrysse 1992). ${ }^{7}$

The highlight of cooperation is probably the periodical Target, founded in 1989 by Gideon Toury of Tel Aviv and José Lambert of Leuven on the basis of shared interests and beliefs. These are manifest in the presentation of the periodical's goals:

Target will orient itself towards the CONTEXTUALIZATION OF TRANSLATION. It will focus on the interdependencies between the position and role of translated texts and translational behavior in culture, the norms that determine their appropriateness and govern their establishment, and the modes of executing translation under various circumstances. (Toury and Lambert 1989; capital letters in the original.)

Beyond Belgium and the Netherlands, the school's conceptions influenced the work of researchers in Germany, Spain, France, Finland and Turkey, and outside Europe especially in Canada. According to Lambert (1995), many researchers throughout the world rely on it at least partially without mentioning it, and perhaps without being aware of its influence on their work.

\section{SHORTCOMINGS}

The enumeration of achievements and successes should not blind one to weak points. The school's continuous struggle at conferences and in publications to have its basic conceptions accepted has not entirely succeeded. These conceptions are far from being universally accepted. The lack of distinction - even the conscious refusal to distinguish - between theorizing and prescribing, which characterized central works in this field (e.g. Newmark 1981), still persists (Nord 1991, is an example).

Moreover, polysystem theory itself, in whose framework the study of translation as described here developed, was to a great extent overshadowed by other theories with which researchers of literature and culture throughout the world are concerned. ${ }^{8}$ This can be attributed to several factors. The school's descriptive works deal mainly with Hebrew culture. This possibly makes them esoteric from an international perspective. Israel's marginal status in the international academic community is another factor. In a marginal posi- 
tion it is difficult to impart any theory, particularly such a demanding one, and one which, if used only partially in combination with other theories, could so easily lead to its complete misinterpretation.

The main difficulty in imparting polysystem theory is that one can hardly accept it without necessarily rejecting modern Western theories dominant today in the study of culture. The rift began with the disagreement of the representatives of polysystem theory with the version of structuralism which developed in France in the 1960s..$^{9}$ The representatives of this version, such as Greimas, Todorov and Genette, themselves followed the theories of the Czech structuralists. But they deviated from viewpoints of their predecessors which the researchers of Tel Aviv saw as their "principles of faith": regarding the text in its historic context, and the attempt to view phenomena in literature without taking any ideological or political sides. Later, structuralism in its French form became an object of attack in France itself and elsewhere. But its successor theories have shared no common ground with polysystem theory either. The post-modernist assertion that there can be no objective observation of reality could not be accepted by those who claim that this is the very observation required for scientific research. Thus polysystem theoreticians had no dialogue with a large part of the research in the West in the fields of literature and culture in general. ${ }^{10}$

\section{A DISCIPLE'S DOUBTS}

The gap described above is real, and the question of whether and how it can be bridged is not easily answered. However, as a disciple of the Tel Aviv school it is my opinion that in order to survive and advance in the intellectual and practical sense, the advocates of polysystem theory may possibly have to address competing modern theories. Various theories of intertextuality (e.g. Riffaterre 1978, 1983) describe the mechanism of text formation differently than it is presented by Even-Zohar using the concepts of repertoire and model. Dialogue, and even confrontation with them, may possibly contribute to the development of polysystem theory more than disregarding them would. In the field of translation studies, theories regarding the alienation from language and addressing the other, developed by such researchers as Barthes, Derrida, Foucault and Lacan, may perhaps explain, from another direction, manipulations performed in the target culture on texts of the culture of origin. ${ }^{11}$ The troubling question is to what extent polysystem theory, and the theory of translation deriving from it, can absorb influences of these "foreign" theories without giving up the basic conceptions forming the very foundation and justification of its existence.

\section{IN PLACE OF A SUMMARY}

Describing a school of thought is an impossible mission. The author is either too distant from the subject, or too close to it (my case). The individuals comprising the group in question do not speak with one voice. Each of them regards other topics in the large framework of "the school's interests" as focal. Moreover, one can hardly condense years of research into one article. It is my hope, nevertheless, that the present review justifies regarding translation studies in the framework of the Tel Aviv school of poetics and semiotics as an approach in its own right. It is distinguished from other approaches by some basic ideas, first and foremost the idea that translation should be studied in the context of the culture receiving it, which is viewed in terms of a system. This basic idea, which is "the invariant under transformation" (to use Toury's maxim of translation), has inspired the school's past achievements and guides it to its future ones. 
Notes

* I wish to thank Prof. Itamar Even-Zohar and Prof. Gideon Toury of Tel Aviv University, and Prof. Nurith Gertz and Ilana Dan of The Open University of Israel, for their helpful remarks.

1. For a review of the history and activity of the Tel Aviv School until the mid-1980s - including controversy over its goals - see Mintz (1984)

2. The name of the department, particularly in English - "The Department of Poetics and Comparative Literature" - is circumstantial and misleading.

3. The branches of literary research and the interaction and links between them were discussed by Hrushovski in a manifesto which opens the first issue of the periodical Ha-Sifrut (Literature) (1968), and in the more elaborate version opening the first issue of PTL (1976). A slightly different scheme of the branches of literary studies was presented by Even-Zohar in the Encyclopaedia Hebraica (1974).

4. Work in English by and on Eastern European formalists and structuralists include: Erlich (1955); Garvin (1964); Matejka and Pomorska (Eds) (1971); Steiner (1984). A collection of essays by Roman Jakobson was published in Hebrew (1986) as part of the Tel Aviv school's efforts to make his works known in Israel.

5. In its target-orientedness - and less in other respects - it is close to the "skopostheorie" which has been developed since the 1970s by Vermeer and his followers (e.g. Vermeer, 1978 and 1992; Reiss and Vermeer 1984; Nord 1991).

6. See Meta vol. 42, n 3, Sept. 1997, pp. 579-586, for a review.

7. The study of translation based on polysystem theory as developed in Europe and especially in Belgium and the Netherlands was recently discussed by Lambert (1995). It is unfortunate that in his essay Tel Aviv is all but missing from the scene in the generation following Even-Zohar and Toury. Hopefully the present review will supplement what is lacking in his, and vice versa. Other references to the study of translation in the framework of polysystem theory include: Holmes et al. (Eds) (1978); Hermans (Ed.) (1985); Roloff (Ed.) (1989); Rabadan (1991); Leuven-Zwart \& Naaijkens (Eds) (1991); Kittel (Ed.) (1992); Gentzler (1993); Roca (1994); Hermans (1995); Bloemen et al. (Eds) (1995).

8. Nevertheless it attracted attention and was reviewed in various works concerning literary theories throughout the world, including: Fokkema and Ibsch (1977); Kushner (Ed.) (1984); Guillen (1985); Dimic \& Garstin (1988); Brunel \& Chevrel (1989); Moisan (1990); Totosy (1992); Bassnett (1993); Pageaux (1994).

9. Even-Zohar referred to the points of the argument in a review appearing in Ha-Sifrut (Literature) in 1977, and in the introduction to the collection of Jakobson's works in Hebrew. His reservations regarding some current trends in cultural studies in the West are mentioned in the introduction to his Polysystem Studies (1990 : 5-6). For a broader discussion, see Feldman (1985).

10. By contrast, there is a sense of closeness to the work of the sociologist Pierre Bourdieu (e.g. Bourdieu 1980) describing culture in terms of "fields" in which power struggles are conducted over "capital" which is specific to the field in question. A collection of his works in Hebrew is forthcoming. An attempt to integrate his conceptions into polysystem theory was made by Sheffy (1992).

11. Derrida has dealt with translation in "Des tours de Babel" (1985) and in other works. Modern Western theories, including Derrida's, were recently used in translation studies by Venuti $(1992,1995)$. First steps towards bridging the gap between these theories and translation studies in the framework of polysystem theory are Raymond van den Broeck's attempt to combine Deconstruction with the school's conceptions (1990) and Lambert's work on translation and the "other" (forthcoming).

\section{REFERENCES}

AMIT-KOCHAVI, Hannah (1993): "Some Aspects of Translations of Israeli Arabic Literature into Hebrew", HaMizrah He-Hadash (The New East - Journal of the Israel Oriental Society), vol. XXXV, a special issue on the literature of the Arabs in Israel, guest editor Ami El'ad, pp. 46-61. (Hebrew, English summary)

AMIT-KOCHAVI, Hanna (in preparation): Translations of Arabic Literature into Hebrew: Their HistoricalCultural Background, Their Characteristics and Their Position within the Target Culture, Doctoral dissertation, Tel Aviv, Tel Aviv University. (Hebrew, English summary)

BASSNETT, Susan (1993): Comparative Literature - A Critical Introduction, Oxford and Cambridge, Blackwell.

BEN-ARI, Nitsa (1988): Norms Underlying Translation of German Literature into English, French and Italian, M.A. thesis, Tel Aviv, Tel Aviv University.

BEN-ARI, Nitsa (1992): "Didactic and Pedagogic Tendencies in the Norms Dictating the Translation of Children's Literature: The Case of Postwar German-Hebrew Translations", Poetics Today, 13 (1), pp. 221230 .

BENHABIB, Doli (1985): A Portrait of the Portrait in Magazines: Profile Models in Two Popular Hebrew Magazines, M.A. thesis, Tel Aviv, Tel Aviv University. 
BEN-SHAHAR, Rina (1983): Dialogue Style in the Hebrew Play, Both Original and Translated from English and French, 1948-1975, Doctoral dissertation (forthcoming in book form), Tel Aviv, Tel Aviv University. (Hebrew, English summary)

BEN-SHAHAR, Rina (1994): "Translating Literary Dialogue: A Problem and Its Implications for Translation in Hebrew", Target, 6 (2), pp. 195-221.

BLOEMEN, Henri, HERTOG, Erik \& Winibert SEGERS (Eds) (1995): Letterlijkheid Woordelijkheid — Literality Verbality, Antwerpen \& Harmelen, Fantom.

BOURDIEU, Pierre (1980): Questions de sociologie, Paris, Minuit.

BROECK, Raymond van den (1990): "Translation Theory after Deconstruction", Patrick Nigel Chaffey, Antin Fougner Rydning and Solveig Schult Ulriksen (Eds), Translation Theory in Scandinavia, Proceedings from the Scandinavian Symposium on Translation Theory (SSOTT III), Oslo, 11-13 August 1988, Oslo, pp. 24-57.

BRUNEL, Pierre et Yves CHEVREL (1989): Précis de littérature comparée, Paris, PUF.

CATTRYSSE, Patrick (1992): "Film (Adaptation) as Translation: Some Methodological Proposals", Target, 4 (1), pp. 53-70.

COSERIU, Eugenio (1988): Schriften von Eugenio Coseriu (1965-1987), Jorn Albrecht (Ed.), Tubingen, Narr.

DERRIDA, Jacques (1985): "Des tours de Babel", Joseph Graham (Ed.), Difference in Translation, Ithaca, Cornell University Press, pp. 196-199, 240-242.

DIMIC, Milan V. and Marguerite K. GARSTIN (1988): The Polysystem Theory - A Brief Introduction, with Bibliography, Edmonton, University of Alberta. [Papers on the Theory and History of Literature, 1.]

DRORY, Rina (1988): The Emergence of Jewish-Arabic Literary Contacts at the Beginning of the Tenth Century, Tel Aviv, The Porter Institute for Poetics and Semiotics and Ha-Kibbutz Ha-Meuchad. (Hebrew)

ERLICH, Victor (1955): Russian Formalism: History, Doctrine, The Hague, Mouton.

EVEN-ZOHAR, Itamar (1971): An Introduction to a Theory of Literary Translation, Doctoral dissertation, Tel Aviv, Tel Aviv University. (Hebrew, English summary)

EVEN-ZOHAR, Itamar (1974): "The Science of Literature", Encyclopaedia Hebraica, vol. 26, pp. $413-419$. (Hebrew)

EVEN-ZOHAR, Itamar (1977): "Works on Poetics and Semiotics", in the section "New Books — Brief Reports", Ha-Sifrut (Literature), 24, pp. 155-156. (Hebrew)

EVEN-ZOHAR, Itamar (1978): Papers in Historical Poetics, Tel Aviv, The Porter Institute for Poetics and Semiotics.

EVEN-ZOHAR, Itamar (1990): Polysystem Studies, a special issue of Poetics Today, 11 (1).

FELDMAN, Yael S. (1985): "Poetics and Politics: Israeli Literary Criticism Between East and West", Proceedings of the American Academy for Jewish Research, vol. LII, pp. 9-35.

FOKKEMA, Douwe W. and Elrud IBSCH (1977): Theories of Literature in the Twentieth Century: Structuralism, Marxism, Aesthetics of Reception, Semiotics, London, Hurst.

GARVIN, Paul L. (Ed. \& tr.) (1964): A Prague School Reader on Esthetics, Literary Structure, and Style, Washington DC, Georgetown University Press.

GENTZLER, Edwin (1993): Contemporary Translation Theories, London \& New York, Routledge (Translation Studies).

GERTZ, Nurith (1987): "My Michael — From Jerusalem to Hollywood via the Red Desert", Leon Yudkin (Ed.), Modern Hebrew Literature in English Translation, New York, Markus Wiener, pp. 139-156.

GERTZ, Nurith (1993): Motion Fiction - Isreali Fiction in Films, Tel Aviv, The Open University of Israel. (Hebrew)

GUILLEN, Claudio (1993): The Challenge of Comparative Literature, tr. Cola Franzen, Cambridge, Harvard University Press.

HERMANS, Theo (Ed.) (1985): The Manipulation of Literature: Studies in Literary Translation, London and Sydney, Croom Helm.

HERMANS, Theo (1995): "Revisiting the Classics — Toury's Empiricism Version One", The Translator, 1 (2), pp. 215-223.

HOLMES, James S. (1988 [1972]): "The Name and Nature of Translation Studies", in his: Translated! Papers on Translation and Translation Studies, Amsterdam, Rodopi, pp. 67-80.

HOLMES, James S., LAMBERT, José \& Raymond van den BROECK (Eds) (1978): Literature and Translation - New Perspectives in Literary Studies, Leuven, Acco.

HRUSHOVSKI, Benjamin (1968): "On the Main Branches of Literary Study", Ha-Sifrut (Literature), 1 (1), pp. 1-10. (Hebrew)

HRUSHOVSKI, Benjamin (1971): "The Major Systems of Hebrew Rhyme from the Piyut to the Present Day (500 a.d. - 1970): An Essay on Basic Concepts", Ha-Sifrut (Literature), 2 (4), pp. 721-749. (Hebrew, English summary)

HRUSHOVSKI, Benjamin (1976): "Poetics, Criticism, Science: Remarks on the Fields and Responsibilities of the Study of Literature", PTL (A Journal for Descriptive Poetics and Theory of Literature), vol. 1, pp. IIIXXXV. 
JAKOBSON, Roman (1959): "On Linguistic Aspects of Translation", Reuben Brower (Ed.), On Translation, Oxford, Oxford University Press, pp. 232-239.

JAKOBSON, Roman (1986): Semiotics, Linguistics, Poetics, Itamar Even-Zohar and Gideon Toury (Eds \& tr.), Tel Aviv, Ha-Kibbutz Ha-Meuchad. (Hebrew)

KAYYAL, Mahmoud (in preparation): Translational Norms in the Translation of Modern Hebrew Literature into Arabic, 1948-1990, Doctoral dissertation, Tel Aviv, Tel Aviv University. (Hebrew)

KITTEL, Harald (Ed.) (1992): Geschichte, System, literarische Übersetzung/ Histories, Systems, Literary Translations, Berlin, Schmidt. [Gottinger Beitrage zur internationalen Übersetzungsforschung, 5.]

KUSHNER, Eva (Ed.) (1984): Renouvellements dans la théorie de l'histoire littéraire, Montréal, McGill.

LAMBERT, José (1995): "Translation, Systems and Research: The Contribution of Polysystem Studies to Translation Studies", TTR, VIII:1, pp. 105-152.

LAMBERT, José (forthcoming): "Translation and the (Non-) Canonization of Otherness".

LEUVEN-ZWART, Kitty M. van and Ton NAAIJKENS (Eds) (1991): Translation Studies: The State of the Art, Proceedings of the First James S. Holmes Symposium on Translation Studies, Amsterdam \& Atlanta (Georgia), Rodopi.

LEVÝ, Jiří (1969 [1963]): Die literarische Übersetzung — Theorie einer Kunstgattung, tr. Walter Schamchula, Frankfurt am Main \& Bonn, Athenaum.

MATEJKA, Ladislav and Krystyna POMORSKA (Eds) (1971): Readings in Russian Poetics, Cambridge (Mass.) and London, The MIT Press.

MINTZ, Alan (1984): "On the Tel Aviv School of Poetics", Prooftexts, 4, pp. 215-235

MOISAN, Clement (1990): L'histoire littéraire, Paris, PUF, coll. «Que sais-je ?», $\mathrm{n}^{\circ} 2540$.

MUKA ŘOVSKÝ, Jan (1970): Aesthetic Function, Norm and Value as Social Facts, tr. Mark E. Suino, Ann Arbor, University of Michigan Press.

NEWMARK, Peter (1981): Approaches to Translation, Oxford, Pergamon.

NORD, Christiane (1991): "Scopos, Loyalty, and Translational Conventions", Target, 3:1, pp. 91-109.

PAGEAUX, Daniel (1994): La littérature comparée, Paris, Colin.

RABADÁN, Rosa (1991): Equivalencia y traducción - Problemática de la equivalencia translémica inglésespañol, Universidad de León.

REISS, Katharina and Hans J. VERMEER (1984): Grundlegung einer allgemeinen Translationstheorie, Tubingen, Niemeyer.

RIFFATERRE, Michael (1978): Semiotics of Poetry, Bloomington and London, Indiana University Press.

RIFFATERRE, Michael (1983): Text Production, tr. Terese Lyons, New York, Columbia University Press.

ROCA, Miguel Gallego (1994): Traducción y Literatura - Los estudios literarios ante las obras traducidas, Ediciones Jucar.

ROLOFF, Hans-Gert (Ed.) (1989): Jahrbuch für internationale Germanistik, XXI:2, Bern, Peter Lang.

SAUSSURE, Ferdinand de (1983 [1916]): Course in General Linguistics, ed. Charles Bally and Albert Sechehaye in collaboration with Albert Reidlinger, tr. and annotated by Roy Harris, London, Duckworth.

SHAVIT, Zohar (1986): Poetics of Children's Literature, Athens and London, The University of Georgia Press.

SHEFFY, Rakefet (1985): Establishment and Canonization in the Evolution of Cultural Systems - The Popular Song as a Test Case, M.A. thesis in Hebrew, Tel Aviv, Tel Aviv University. (English summary)

SHEFFY, Rakefet (1992): Repertoire Formation in the Canonization of Late 18th Century German Novel, Doctoral dissertation, Tel Aviv, Tel Aviv University.

SHLESINGER, Miriam (1989a): Simultaneous Interpretation as a Factor in Effecting Shifts in the Position of Texts on the Oral-Literate Continuum, M.A. thesis, Tel Aviv, Tel Aviv University.

SHLESINGER, Miriam (1989b): "Extending the Theory of Translation to Interpretation: Norms as a Case in Point", Target, 1:1, pp. 111-115.

STEINER, Peter (1984): Russian Formalism - A Metapoetics, Ithaca and London, Cornell University Press.

TOTOSY de Zepetnek, Steven (1992): "Systemic Approaches to Literature — An Introduction with Selected Bibliographies", Canadian Review of Comparative Literature, XIX:1-2, pp. 21-93.

TOURY, Gideon (1974): "Spoken Hebrew — a Legitimate Language for Literary Translation", Siman Kri'a, 3/4, pp. 366-371. (In Hebrew)

TOURY, Gideon (1977): Translational Norms and Literary Translation into Hebrew, 1930-1945, Tel Aviv, The Porter Institute for Poetics and Semiotics. (In Hebrew)

TOURY, Gideon (1980): In Search of a Theory of Translation, Tel Aviv, The Porter Institute for Poetics and Semiotics.

TOURY, Gideon (1995): Descriptive Translation Studies and Beyond, Amsterdam \& Philadelphia, John Benjamins.

TOURY, Gideon and José LAMBERT (1989): "On Target's Targets", Target, 1:1, pp. 1-7.

VENUTI, Lawrence (Ed.) (1992): Rethinking Translation - Discourse, Subjectivity, Ideology, London \& New York, Routledge.

VENUTI, Lawrence (1995): The Translator's Invisibility - A History of Translation, New York, Routledge. 
VERMEER, Hans J. (1978): "Ein Rahmen für eine allgemeine Translationstheorie", Lebende Sprachen, 23, pp. 99-102. [Rep. in Vermmeer 1983: 48-61.]

VERMEER, Hans J. (1983): Aufsatze zur Translationstheorie, Heidelberg.

VERMEER, Hans J. (1992): Skizzen zu einer Geschichte der Translation, 1-2, Frankfurt, IKO — Verlag für interkulturelle Kommunikation.

WEISSBROD, Rachel (1991): "Translation of Prose Fiction from English to Hebrew: A Function of Norms (1960s and 1970s)", Mildred L. Larson (Ed.), ATA, vol. V, New York, State University of New York, pp. 206-223. [Summary of a doctoral dissertation in Hebrerw, 1989.]

WEISSBROD, Rachel (forthcoming): "Exodus: the Novel, the Film, and Israeli Culture", Nurith Gertz, Orly Lubin and Judd Ne'eman (Eds), Israeli Cinema: An Anthology, Tel Aviv, The Open University of Israel. (In Hebrew)

YAHALOM, Shelly (1980): "Du non-littéraire au littéraire", Poétique, 44, pp. 406-421.

YAHALOM, Shelly (1981): "Le système littéraire en état de crise: Contacts inter-systémiques et comportement traductionnel", Poetics Today, 2:4, pp. 143-160. 